\title{
Evolution in Financial Investors' Engagement in Commodity Markets
}

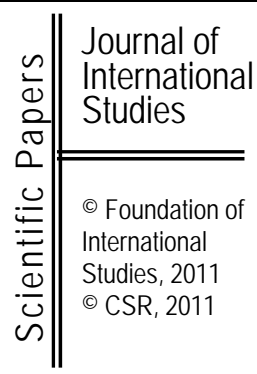

Prof. Jerzy Dudziński

Department of Foreign Trade and International

Economic Relations

Faculty of Economics and Management

University of Srazecin

mikmakhz@wneiz:pl

\begin{abstract}
The involvement of financial investors in commodity markets has been an important phenomenon observed in the last decade as a determinant of the tendencies in the world commodity prices. In the post-crisis period (since 2009) this involvement has both intensified and become more diverse thus changing the structure of the commodity assets under management.
\end{abstract} Submitted: September, 2011 $1^{\text {st }}$ revision: October, 2011 Accepted: October, 2011

Keywords: Financial Crises, International Financial Markets, Financialisation, Commodity Markets, World Prices.

JEL classification: F39, G01, G15.

\section{Introduction}

The presence of financial investors in commodity markets is a relatively new phenomenon. It became more visible in the late 2000s and intensified at the beginning of the current decade. These issues still need further exploration although the recent years have witnessed a body of literature on both theoretical and practical aspects of these issues appear in the market.

The effects of financial investors' involvement in commodity markets are reflected mostly in the movements of the world prices of food and resources which are then transferred to international trade. Thus this form of activity affects indirectly also the economic growth of individual countries and regions.

The aim of the paper is to present the directions of evolution of financial investors' involvement, particularly in terms of the changes initiated by the financial crisis. Part one shows the premises and determinants of financial investors' engagement in commodity markets. Part two analyses the forms of this activity as well as the directions of and reasons for changes in this field. The last part presents the remarks on the outlook for the development of the analysed phenomenon. Particular attention has been paid to the regulations and limitations of the engagement of financial investors - a topic widely discussed at the moment.

\section{Premises and determinants of financial investors' activity}

Till the beginning of the last decade financial investors, when constructing their portfolios, were considering mostly traditional assets such as stocks, bonds or real estate. 
Later, however, along with the development of the modern portfolio theory, they began to pay more attention to and include in their portfolios the so-called alternative financial instruments, such as contracts for selected groups of primary commodities. In that time, despite a relatively high liquidity of futures contracts for commodities, their price movements were not related to the prices of typical financial assets. They were in particular loosely related to stock prices as well as other goods in the entire group of commodities. As a result, one was able to observe a certain isolation of commodity price movements from those of classical financial assets on the one hand, and (at least partial) segmentation of prices within the whole group of commodities on the other. In this aspect those tendencies differed from typical financial assets whose prices are clearly and strongly interrelated.

The 2000 slump in the stock market and the publications on the negative correlation between returns on shares and commodity contracts encouraged financial investors to use the latter to reduce their portfolio risk. This in turn enabled investment banks to promote commodity contracts as a new category of financial assets. As a consequence, a huge wave of resources flooded commodity markets and targeted various financial instruments related to commodity contracts. It laid grounds for the process known as financialisation of commodity markets. One expression of this phenomenon is the strengthening comovement of the prices of commodities and classical financial assets as well as within the “commodities" group alone (Dudziński, 2011, pp. 58-60).

An important determinant of this huge inflow of resources for investment in commodities was also the fact that at a time of increasing inflation the attractiveness of classical assets such as stocks and bonds was decreasing, unlike in the case of commoditybased investments. The latter became a good instrument of protection against inflation (Stoll, Whaley, 2009, pp. 4-5, The Financialization, 2009).

Globalisation and deregulation processes in the economy were important factors encouraging the activity of financial investors in commodity markets. In the literature a view is common that the "(...) insufficient supervision in the international markets was (..) a major driver of the global increases in commodity prices (Sławiński, 2010, p. 146). The key role is attributed to the passing of the Commodity Futures Modernization Act in 2000 which excluded interbank markets from the regulations of the 1936 Commodity Exchange Act that regulated the trade in commodity markets. As a consequence the provisions limiting speculation were waived, and most of the commodity contracts were no longer under supervision (Sławiński, 2010, p. 156).

The enhancement of the market infrastructure for commodity futures markets was the next factor contributing to the expansion of the financial investor in commodity investments. There was progress during the period between 2003 and 2004, including the further development of commodity indexes and the creation of ETFs. Furthermore, the improvement of trading-related platforms, such as the introduction of an electronic trading platform by the NYMEX in 2006, reduced transaction costs and accelerated transaction settlements in commodity futures markets (see: Chart 1). 


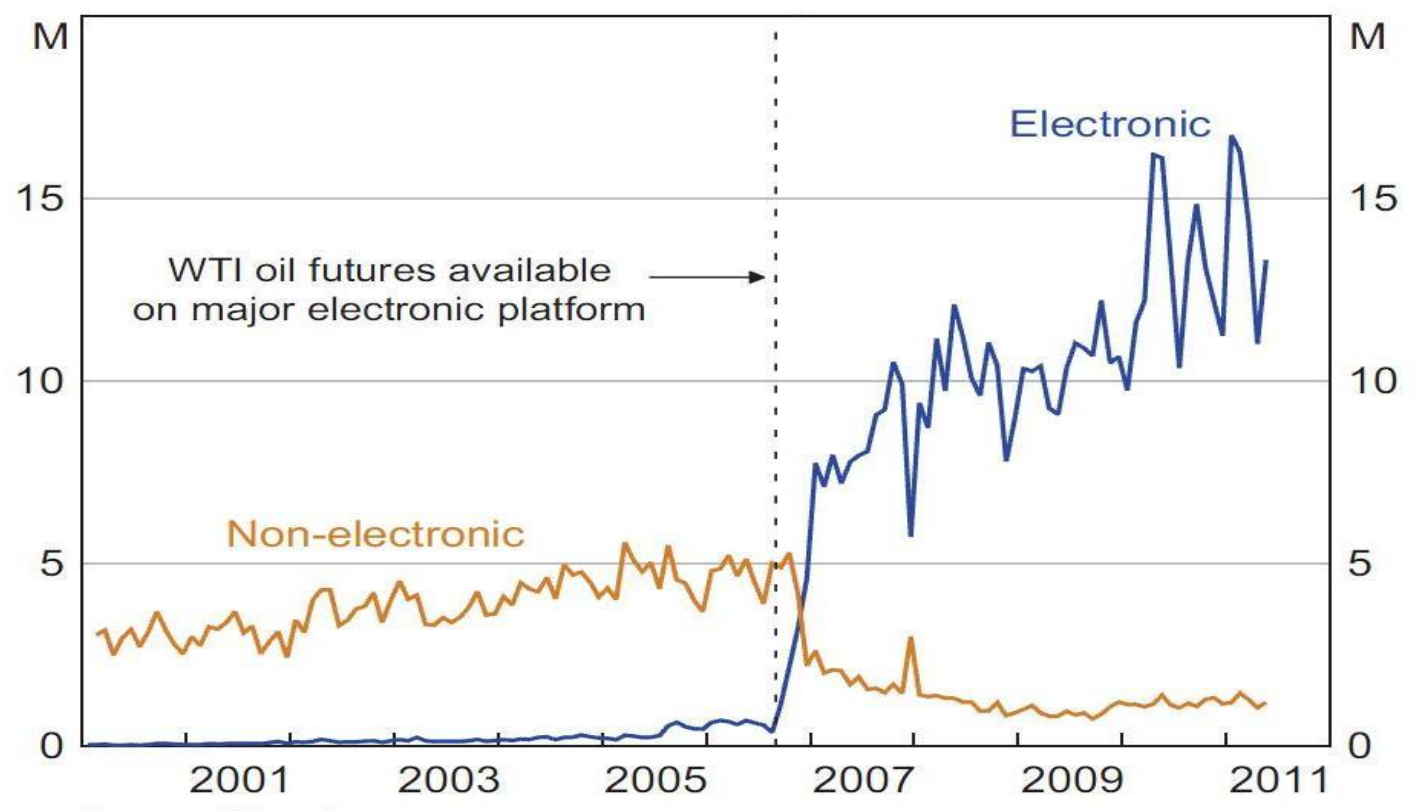

Chart 1. Trading In WTI Oil Futures (Volume, contracts per month)

Source: A. Dwyer, S. Gardner, T. Williams, Global Commodity Markets - Price Volatility and Financialization, Bulletin Reserve Bank of Australia, June 2011, p. 53.

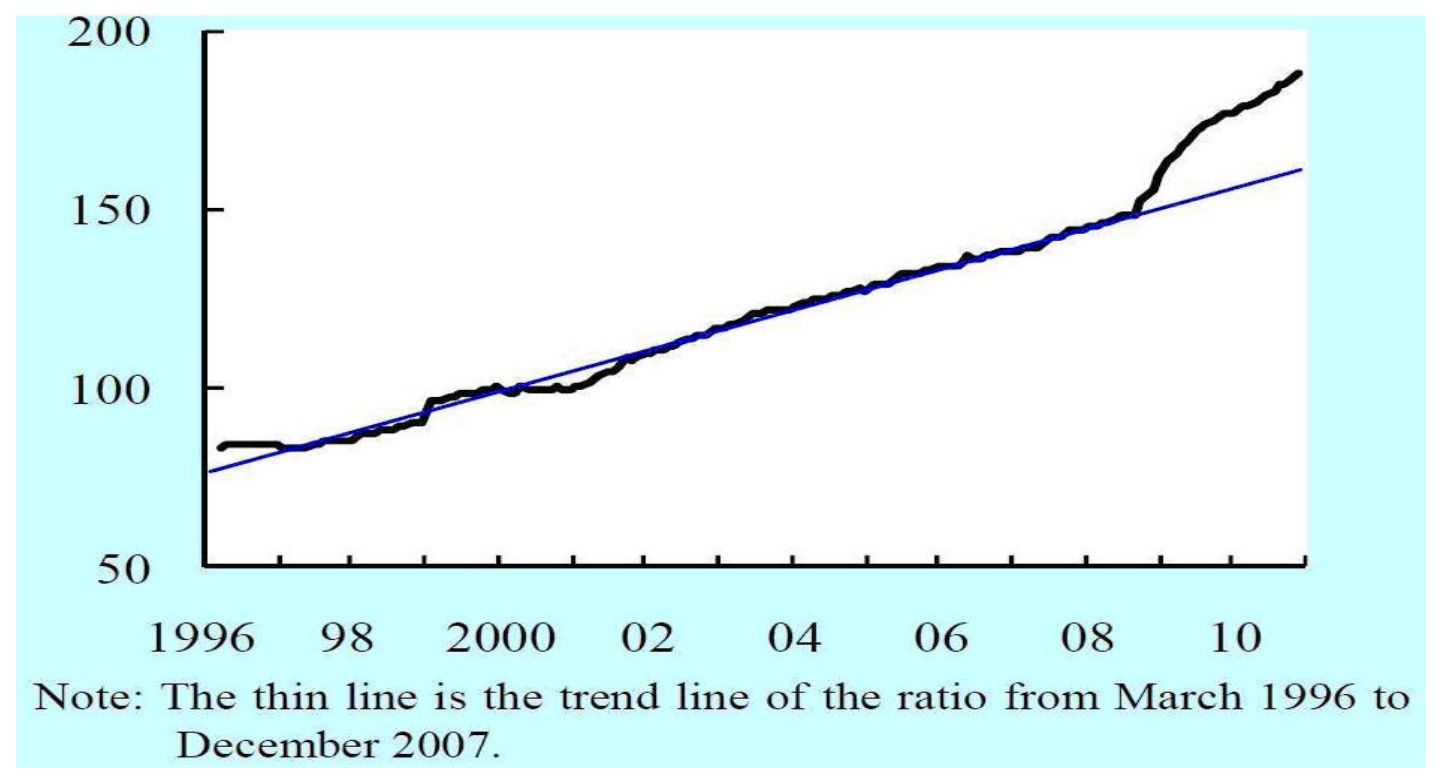

Chart 2. Global M1 to Global GDP Ratio (Jan. $2000=100)$

Source: Y. Inamura, T. Kimata, T. Kimura, T. Muto, Recent Surge In Global Commodity Prices, Bank Japan Review March 2011, p. 8.

Monetary policy was an additional factor which reinforced the financialisation in commodity markets after 2008 . The literature shows that globally accommodative monetary conditions have become unprecedented. The relative size of global money stock (M1) measured against the real GDP has surpassed its historical trend (Chart 2). This sustained global excess liquidity not only increases physical demand for commodities thereby affecting fundamentals, but also amplifies speculative factors, both of which are contributing to the sharp rise in global commodity prices (Inamura, Kimata, Kimura, Muto, 2011, p. 8). 


\section{The scale and dynamics of financial investors' involvement in commodity markets}

Financial investors' involvement is described in various ways, usually in the form of estimates published by various banks. Bank of International Settlement (BIS) in its BIS Quarterly Review publishes figures describing the involvement of financial investors in the OTC market. This data concerns commodity-based derivatives and is published as the socalled Notional amounts outstanding and Gross market values, both denominated in USD. In its quarterly, BIS presents also the scale of financial investors' involvement in organised exchanges with respect to futures and options. This data is available as the contracts outstanding and turnover, and is shown as the number of contracts.

Barclays Capital Bank in its publication The Commodity Investor investigates, in turn, the scale of involvement of financial investors in commodity markets, expressed as the Assets under management by types of financial products (ETP, Medium-term notes and Bercap estimates indices). The latter describe the bank's estimates of the scale of involvement of one particular group of investors - commodity index traders (CIT). Their engagement in the assets in question is denominated in USD.

It should be pointed out that there are several approaches one might adopt to explore scale of financial investors' involvement in commodity markets. It is noteworthy to observe here that the figures published in various sources are only estimates which are usually adjusted in the future.

The dynamics of the inflow of money to commodity markets is best reflected in the fact that in the years 2001-2011 alone the value of the commodity assets under management increased by approx. 50 times, reaching USD 412 billion in the first quarter of 2011 (Dudziński, 2011, p. 69, Barclays Bank, 2011, Dwyer, Gardner, Williams, 2011, p. 53).

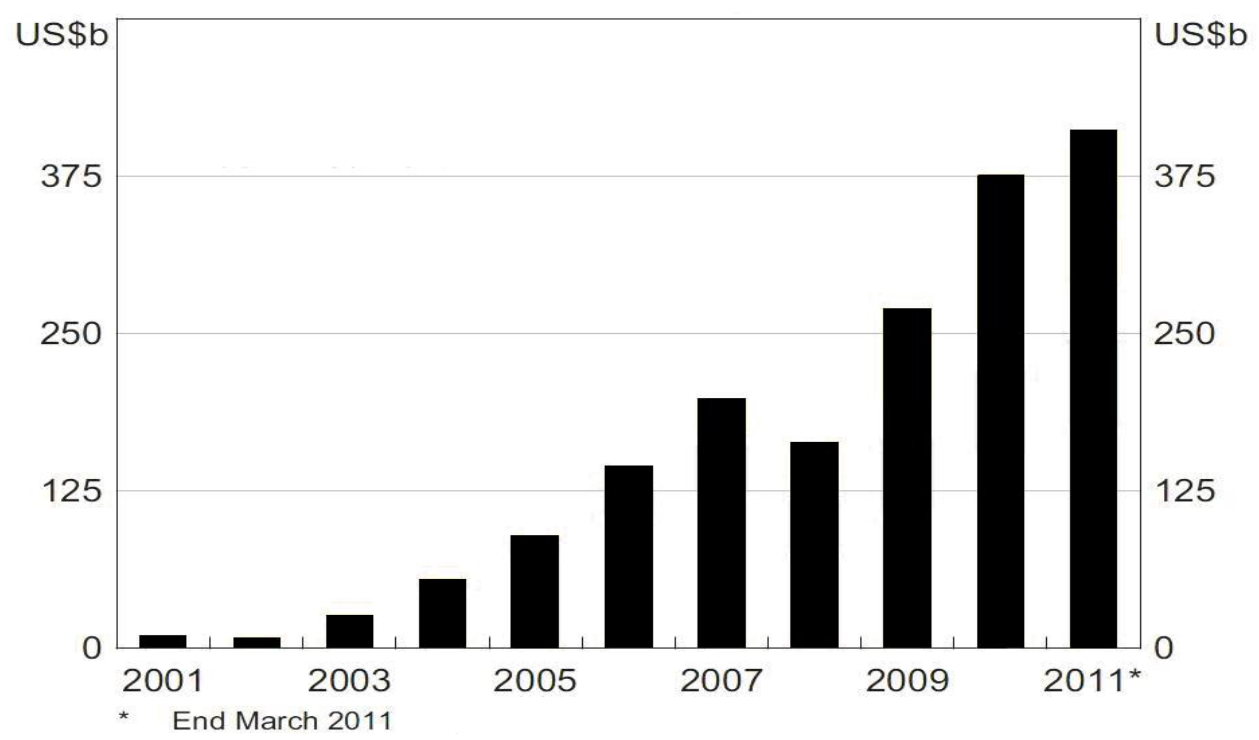

Chart 3. Commodity Investment. Assets under Management in the Years 2001-2011 (USD billions)

Source: Barclays Capital.

In the second half of the decade particularly high dynamics was observed for precious metal ETPs, which noted a more than 20-fold increase, and other ETPs - a 43-fold increase (see: Table 1).

It is also noteworthy to point out that in the years 2001-2008 the notional value on the OTC market (commodity-based derivatives) rose more than twenty times, reaching more than 
USD 13 trillion in June 2008, whereas the total notional value in the OTC market increased approx. seven times. Particularly high dynamics were observed for commodities in the years 2005-2006, when they nearly doubled over a year (whereas the total OTC notional value in that period increased by $30 \%$ ). As a result, the ratio of commodity contracts to the total notional value of the OTC market increased from $0.6 \%$ in 2004 to nearly $2 \%$ in 2008 (Dudziński, 2011, p. 67).

Table 1. Dynamics of Commodity Assets under Management in the Years 2006 - 2011 (2005 $=100)$

\begin{tabular}{|l|r|r|r|r|r|r|}
\hline & $\mathbf{2 0 0 6}$ & $\mathbf{2 0 0 7}$ & $\mathbf{2 0 0 8}$ & $\mathbf{2 0 0 9}$ & $\mathbf{2 0 1 0}$ & $\mathbf{2 0 1 1}^{\mathbf{a}}$ \\
\hline CIT & 140 & 167 & 87 & 148 & 206 & 237 \\
\hline Precious ETPs & 252 & 472 & 672 & 1327 & 2181 & 2236 \\
\hline Other ETPs & 130 & 1001 & 1006 & 3006 & 3500 & 4370 \\
\hline $\begin{array}{l}\text { Medium-term } \\
\text { Notes }\end{array}$ & 244 & 377 & 522 & 611 & 722 & 755 \\
\hline
\end{tabular}

${ }^{\text {a }} 1^{\text {st }}$ quarter.

Source: Own calculations based on the data published by the Barclays Capital.

Ratio of commodity contracts in the total amount of derivatives traded in organised exchanges was gradually rising. It is particularly well noticeable for futures contracts. The ratio of commodity contracts in all the futures contracts outstanding in organised exchanges increased from $10.6 \%$ in 2005 to as much as $42.6 \%$ in 2010 . The phenomenon was clearly visible especially in the years 2009-2010 (as in 2008 this ratio was still at the level of only $18.2 \%$ ). It may be therefore concluded that the centre of gravity in financial investments has recently shifted from the OTC market (following the withdrawal of investors) to organised exchanges, mostly in the form of futures and - to a lower degree - also option contracts (Dudziński, 2011, p. 70).

\section{Commodity contracts as financial assets}

In the first part of the paper the reasons for and determinants of the financialisation processes in commodity markets have been explored. Following the impact of the aforementioned financial factors such as stock or bonds, etc., commodity contracts were considered another group of assets and as such they contributed to higher correlation coefficients between stock and commodity. This phenomenon has been illustrated in Chart 4 .

Chart 4 reveals that the correlation between stock and commodity prices used to be very weak in the past, sometimes even negative. Recently, however, following the surge in the financial investors' involvement, the degree of this correlation increased dramatically to 0.8 . 


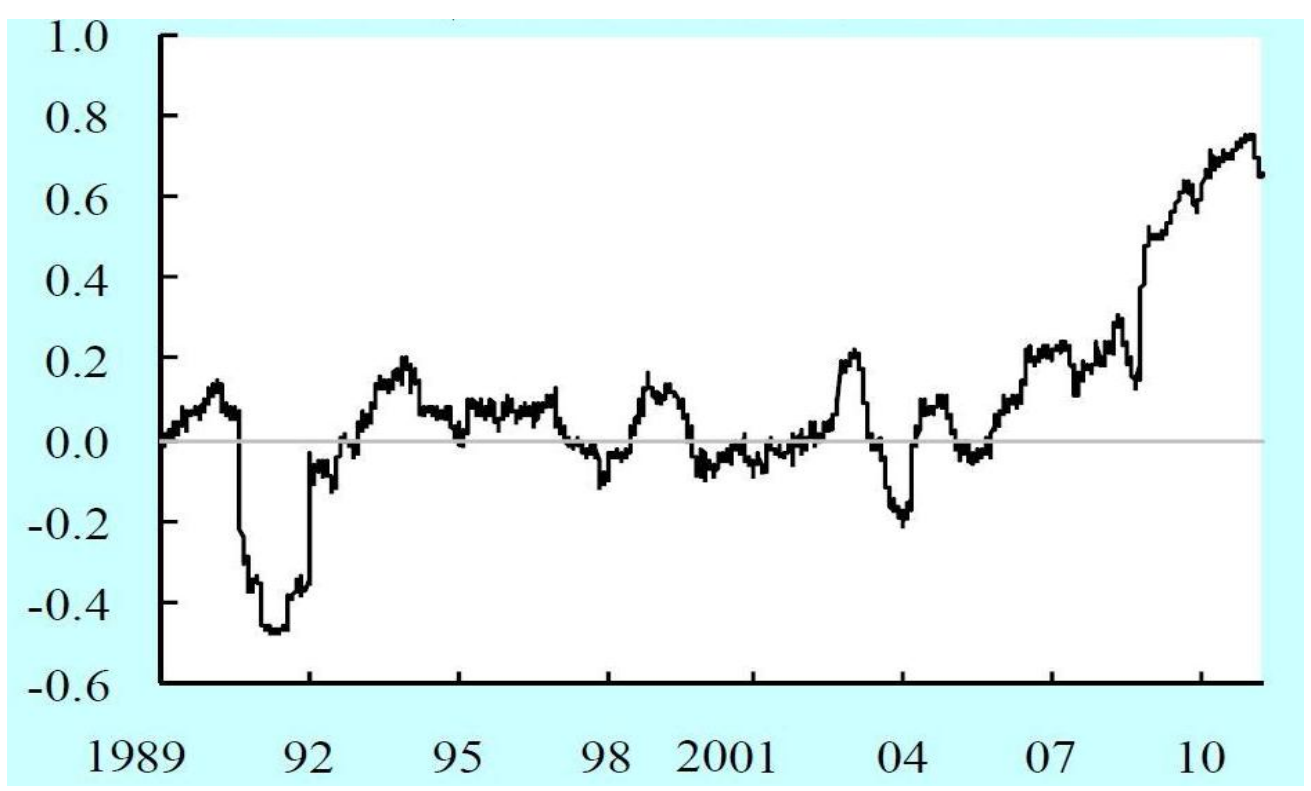

Note: The figure shows the one-year rolling correlation between the daily return of the global equity index (MSCI AC-World) and that of the commodity index (S\&P GSCI).

Chart 4. Return Correlation between Commodity Index and Equity Index

Source: Y. Inamura, T. Kimata, T. Kimura, T. Muto, Recent Surge In Global Commodity Prices, Bank Japan Review March 2011, p.7.

This process is still more evident in Chart 5 which depicts the Dow Jones Industrial Average index next to the IMF commodity price index for the years 2008-2011, i.e. in the phase of a dramatic fall in the prices and their subsequent growth following the post-crisis recovery. It should be emphasised that the correlation coefficient between the two indices amounted to as much as 0.92 (the author's own estimates), which reveals a very strong correlation between the two variables and provides evidence supporting the thesis of the transformation of commodity contracts into a certain form of financial assets.

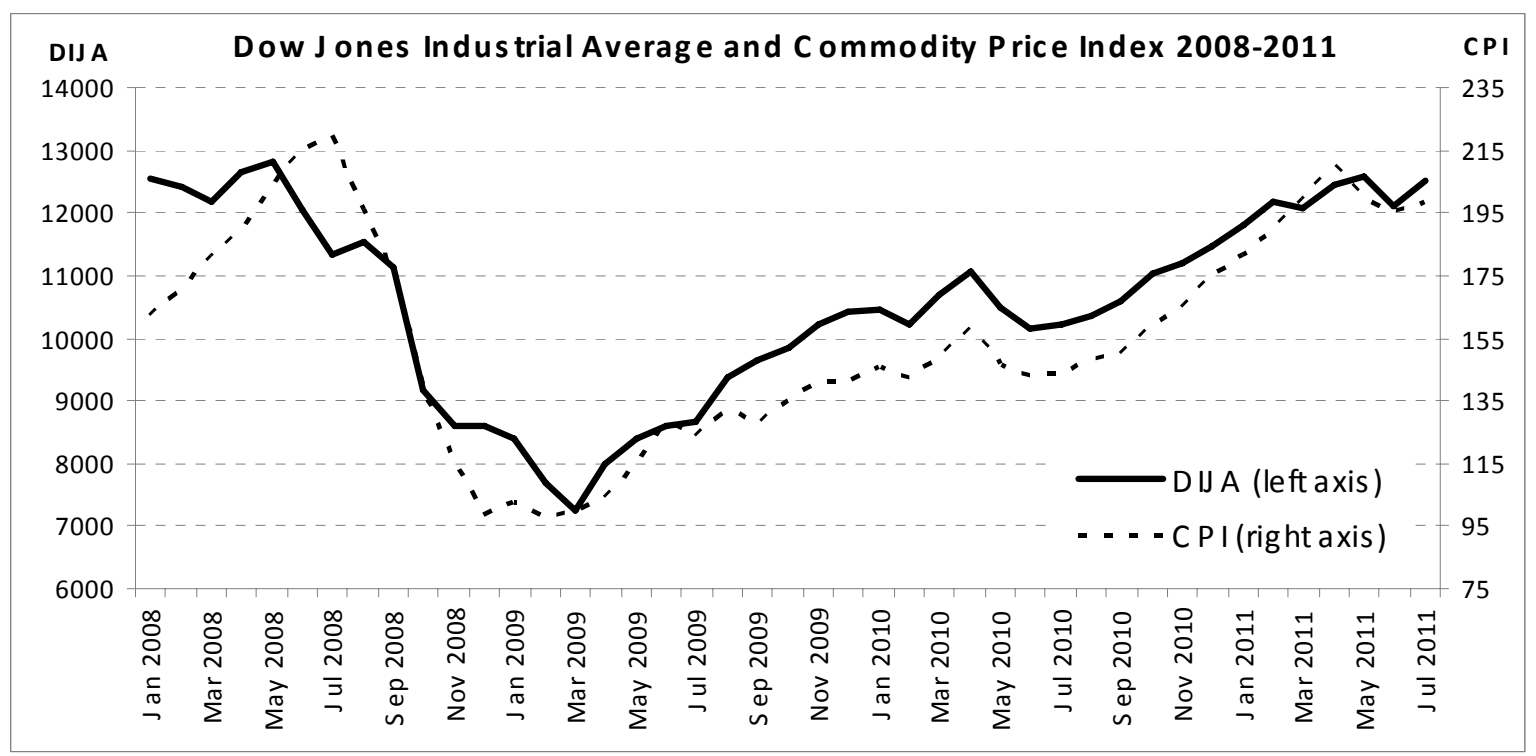

Chart 5. Dow Jones Industrial Average and Commodity Price Index 2008 - 2011

Source: Commodity Price Index, Monthly Price, 
http://www.indexmundi.com/commodities/?commodity=commodity-priceindex\&months=240; Dow Jones Industrial Average, Historical Prices, http://finance.yahoo.com/q/hp?s=^dji+historical + prices.

It is also noteworthy to point out that - as published in the body of literature on the subject - the behaviour of commodity prices, especially oil, over the business cycle has changed fundamentally. In the most recent business cycles commodity prices and equity prices evolved differently. Increases in commodity prices did not occur until well after the trough. In the most recent business cycle, on the other hand, oil prices surged immediately after the trough, even before share prices started to rise. This surge was based simply on the expectation, not the actual occurrence, of an upswing (Formation, 2011, p. VIII).

Table 2. Physical and Financial Market Size of Major Commodities (X 2009, US\$ billions)

\begin{tabular}{|l|c|c|c|c|c|}
\hline & \multicolumn{3}{|c|}{} & \multicolumn{2}{c|}{$\begin{array}{c}\text { Financial market } \\
\text { (exchange traded) }\end{array}$} \\
\hline & $\begin{array}{c}\text { Annual } \\
\text { production }\end{array}$ & $\begin{array}{c}\text { Annual } \\
\text { exports }\end{array}$ & $\begin{array}{c}\text { Inventories } \\
\text { (end period) }\end{array}$ & $\begin{array}{c}\text { Annual } \\
\text { turnover }\end{array}$ & $\begin{array}{c}\text { Open } \\
\text { interest }^{\mathrm{b}}\end{array}$ \\
\hline Oil $^{\mathrm{c}}$ & 2395 & $206^{\mathrm{e}}$ & 312 & 22843 & 193 \\
\hline Natural gas $^{\mathrm{d}}$ & 584 & 67 & na & 2084 & 29 \\
\hline Coal $^{\mathrm{e}}$ & 844 & 124 & na & 24 & 4 \\
\hline Copper $^{\mathrm{e}}$ & $143^{\mathrm{f}}$ & $44^{\mathrm{d}}$ & 6 & 10891 & 81 \\
\hline Iron ore $^{\mathrm{d}}$ & 222 & 117 & na & na & $\mathrm{Na}$ \\
\hline Gold $^{\mathrm{e}}$ & 104 & na & na & 6249 & 76 \\
\hline Corn & 130 & 16 & 23 & 1093 & 20 \\
\hline Wheat & 143 & 28 & 41 & 602 & 14 \\
\hline Soybeans & 199 & 68 & 29 & 4775 & 41 \\
\hline Rice & 235 & 16 & 50 & 35 & 1 \\
\hline Sugar & 81 & 27 & 14 & 4425 & 27 \\
\hline
\end{tabular}

${ }^{a}$ RBA estimates based on volumes and indicative world prices.

${ }^{\mathrm{b}}$ Average of open interest outstanding at the end of each month.

${ }^{c}$ Export and inventory figures fir OECD economies.

${ }^{\mathrm{d}}$ Physical market data are for 2009 calendar year.

${ }^{\mathrm{e}}$ Physical market data are for 2010 calendar year.

${ }^{\mathrm{f}}$ This figure is for new production only and does not include scrap metal supply.

Sources: ABARES; Bloomberg; CFTC; IEA; RBA; USD quoted after: sources for Chart 1.

This more intense involvement of financial investors in commodity market and financialisation processes exerts an impact on the relation of the annual turnover in the financial market to the total output and exports of individual commodities. These relations for the end of 2009 have been presented in Table 2.

The data shows, for instance, that the annual turnover in oil commodity exchanges is nearly 10 times higher than the annual production of this commodity and as much as 100 higher than its annual exports. Still greater differences are reported for copper, gold and soybeans.

Interesting evidence of the scale of financialisation in commodity markets may be found in the literature. It is pointed out, for instance, that a barrel of oil might be traded 20 times before it is delivered to the end user. The airlines believe that speculation adds $\$ 30$ to $\$ 60$ to the per-barrel price. Tyson Foods (2008) has also been vocal in its belief that speculators are driving up the price of agricultural commodities (hence, increasing the cost of 
producing poultry). Long-only indexers hold contracts equal to 33-65 percent of the corn, soybean and wheat crops (Wray, p. 35).

\section{Phases of activity}

The analysis carried out so far shows that financial investors' involvement in commodity markets has been undergoing a certain evolution in terms of both forms and direction of their involvement. Whereas in the first period the vast majority of resources was invested using the buy and hold strategies, characteristic of index traders, in the post-crisis recovery period this strategy changes. At present it is money managers who adopt an active investment strategy that dominate among investors in the market. It is reflected in the structure of commodity assets under management as shown in Table 3. In 2005 investment made by index traders represented the vast majority - they accounted for as much as $83 \%$ of the total amount. In 2010 this share dropped to mere 41\%. A surge, on the other hand, was observed for the share of ETPs, i.e. financial instruments used by money managers (from $7 \%$ in 2005 to more than $40 \%$ in 2010). It was related, naturally, to high dynamics of investment in ETP in the years 2006-2011, as mentioned above (see: Table 1).

Table 3. The Structure of Commodity Investment. Assets under Management in the Years 2005-2011 (as \%)

\begin{tabular}{|l|r|r|r|r|r|r|r|}
\hline & $\mathbf{2 0 0 5}$ & $\mathbf{2 0 0 6}$ & $\mathbf{2 0 0 7}$ & $\mathbf{2 0 0 8}$ & $\mathbf{2 0 0 9}$ & $\mathbf{2 0 1 0}$ & $\mathbf{2 0 1 1}^{\mathbf{a}}$ \\
\hline Total & 100 & 100 & 100 & 100 & 100 & 100 & 100 \\
\hline CiT & 83 & 74 & 65 & 41 & 41 & 41 & 43 \\
\hline Precious ETPs & 6 & 10 & 13 & 23 & 27 & 32 & 30 \\
\hline Other ETPs & 1 & 1 & 5 & 7 & 11 & 10 & 11 \\
\hline $\begin{array}{l}\text { Medium-term } \\
\text { Notes }\end{array}$ & 10 & 15 & 17 & 29 & 21 & 17 & 16 \\
\hline
\end{tabular}

${ }^{\mathrm{a}} 1^{\text {st }}$ quarter.

Source: as for Table 1.

An interesting study was made by UNCTAD experts. They found out that the changes in commodity prices were strongly correlated with the changes in the positions taken by money managers. The correlation between prices and the changes in the positions taken by index traders, in turn, is very weak or even negative. For instance, with respect to oil, the correlation between the changes in the price and positions taken by investors between June 2009 and February 2011 amounted to 0.81 for money managers and only 0.18 for index traders. The estimates of both coefficients for three other commodities - corn, sugar and wheat - amounted, respectively, to: 0.52 and 0.08 for corn, 0.52 and 0.12 for sugar, and 0.56 and 0.09 for wheat (Formation, 2011, p. 18).

This decreasing role of index traders is reflected directly in the data shown in Table 4. It presents the scale of financial investors' involvement in the OTC market and organized exchanges. Between July 2008, i.e. the peak of investors' engagement in commodity markets (with maximum prices) and the first quarter of the year 2011, the OTC market notional value for commodity-based derivatives dropped in absolute figures nearly five times whereas the total futures and option volume increased by more than $25 \%$. 
Table 4. Changes in the Involvement of Financial Investors in the OTC Market and Organised Exchanges between June 2008 and March 2011 (VI $2008=100$ )

\begin{tabular}{|c|r|r|}
\hline & OTC & FIO $^{\mathbf{a}}$ \\
\hline VI 2008 & 100 & 100 \\
\hline XII 2008 & 33.5 & 76.3 \\
\hline VI 2009 & 27.4 & 96.3 \\
\hline XII 2009 & 22.3 & 114.4 \\
\hline VI 2010 & 21.6 & 105.1 \\
\hline XII 2010 & 22.1 & 121.2 \\
\hline III 2011 & n/a & 125.8 \\
\hline
\end{tabular}

${ }^{a}$ Futures and Options.

Source: own calculations based on BIS Quarterly Review (several issues).

While index traders, as mentioned above, pursue a passive investment policy, money managers generally have a short-term perspective and adopt an active investment strategy. This strategy goes beyond the consideration of commodities as a fairly homogenous asset class with a unique risk premium, which is characteristic of broad-based passive index investment; it also takes into account factors such as different short-term supply-and-demand dynamics, as between industrial metals and energy. As UNCTAD claim (Formation, 2011, p. 28), perhaps more importantly, active trading strategies try to take advantage of profitable investment opportunities arising:

a) in declining markets (by taking "short" in addition to "long" positions);

b) from taking longer dated futures positions than those usually included in readily available indexes;

c) from trading commodities that are barely, if at all, included in the popular commodity indexes (e.g. soybean oil is not included in the S\&P GSCI, while cocoa is not included in the DJ-UBSCI); and

d) from employing a "relative value" approach, such as by exploiting differences in quality (e.g. WTI versus Brent crude oil), regional dynamics (e.g. North America and Western Europe versus Asia), intracommodity dynamics (e.g. soybeans versus soybean oil), and crosscommodity dynamics (e.g. trading oil and feedstock used for biofuel production against other food commodities).

The money managers category includes a range of investors, such as hedge funds and institutional investors. These investors follow different trading strategies based on macroeconomic fundamentals, detailed commodity research, algorithmic trading or trend following, and general financial portfolio-diversification considerations. Money manager are able to adjust their exposure in commodity markets according to changes in asset prices with a view to stabilizing the structure of their portfolio (Formation, 2011, p. 28).

The literature presents also another possible explanation for the decreasing role of the OTC market as the target for investors' resources - government regulations limiting this activity (Basu, Gavin, 2011, pp. 36-47). These regulations as well as other proposals to introduce regulations in derivative trading by banks and improve the transparency of the OTC market have significantly reduced the scale of financial investors' involvement in this market and - beyond doubt - contributed to the changes in the strategies and forms of their activity.

\section{Outlook for investors' activity in the light of market regulation initiatives}

The negative effects of financialisation in the contemporary economy, including 
commodity markets, have recently encouraged several attempts to introduce (both national and international) regulations to the aforementioned markets. The United States (particularly Dodd - Frank Wall Street Reform and Consumer Protection) have been witnessing this phenomenon to a greater extent than Europe. It is also widely discussed what measures should be taken to improve the efficiency of commodity markets (both organized exchanges and the OTC). UNCTAD and FAO are leaders in discussing and suggesting new solutions. The preceding, due to the relevance of commodities to developing economies, and the latter owing to the relevance of these markets to the global agriculture.

UNCTAD studies emphasise several issues related to the operation of commodity markets (Formation, 2011, p. VIII - IX). Firstly, it is argued that there is a need for increased transparency in the exchanges and OTC markets themselves. More information should be made available with regard to position-taking and categories of market participants in commodity derivatives markets. This applies in particular to commodity trading in Europe, where transparency lags significantly behind that in United States exchanges. Improved transparency is important not only for market participants but also for regulators, who can only intervene if they know what is happening in the market.

Secondly, the issue of tighter regulation of financial players is raised. Tighter rules internationally would be an optimal scenario, so that regulatory migration could be avoided. Given that the size of financial players' involvement has a substantial impact on price developments, position limits aimed at restraining the engagement of financial investors in commodity markets may be indispensable in the medium to long run.

Thirdly, a number of direct commodity price stabilization measures are considered. As governments and international institutions have access to the same kind of information as the market participants, the establishment of a government-administered virtual reserve mechanism and the possibility of allowing governments' direct intervention in the physical and the financial markets need to be considered. It is believed that in financialized commodity markets, intervention may even help market participants to better recognize the fundamentals.

Fourthly, it is argued that the introduction of a transaction tax system - a problem which has been widely discussed recently - could generally slow down the activities of financial investors in commodity markets. Regardless of the problems related to the regulation of markets, one also points out to the need to enhance the market information. Although a variety of sources of information currently exist, there is substantial uncertainty in terms of data quality and timeliness, particularly with respect to inventories (Formation, 2011, p. IX).

In its publications, the FAO concentrates on more specific problems. They emphasise mostly the need to establish a trade depository to register OTC contracts, in line with earlier decisions in the G20 Summit in 2009 in Pittsburgh. It is postulated that there should be maximum limits to daily price changes to reduce volatility. The use of speculative position limits on commodity futures contracts to ensure control of undue market influence is widely found a necessity. It is also raised that the limits on inventories held in delivery warehouses by non-commercial entities should be introduced so as to limit market manipulation possibilities. Another important issue is the postulate to provide provisions for high volume and frequency trading into the regulatory regime. It should be also emphasised that the FAO experts argue that changes in regulation should be widely adopted across commodity exchanges and across commodities in order to avoid the migration of participants and regulatory arbitrage (Price Volatility, 2011, p. 23).

Finally, it should be observed that the European Commission is also considering appropriate measures to limit speculation in commodity markets. They aim, for instance, to force traders to disclose their position and imposing so-called "position limits" to stop megatrades that could upset markets (EU wants to tame financialisation, 2011). 


\section{Final remarks/conclusions}

The analysis carried out in the paper allows several generalisations to be made. Firstly, the increasing intensity of financial investors' involvement in commodity markets was undoubtedly related to the pressures of globalisation and deregulation observed across the world. Secondly, the investors' engagement has become more and more visible in the current post-crisis period (since 2009). Thirdly, at present we are witnessing changes in terms of both forms and directions of investors' activities - in general they come down to the decreasing role of formerly dominant index traders who tend to pursue passive investment strategies. It is money managers who invest more aggressively and introduce new financial instruments (such as ETPs) that become the major players. These phenomena explain also the diminishing role of the OTC market (as index traders usually acted through swap dealers operating in this market). Fourthly, the outlook for financial investors in commodity market is determined by two factors. On the one hand, the scale and form of this activity will affect the solutions concerning the regulation of (mostly financial) markets, which is widely discussed at present. On the other hand, the scale of investors' involvement will be determined by the condition of the global economy. It is noteworthy to point here that the 2008 financial crisis has significantly reduced the activity of the aforementioned investors in both commodity markets, and financial markets in general.

\section{References}

Basu, P., Gavin, W. T. (2011), What Explains the Growth in Commodity Derivatives?, Federal Reserve Bank of St. Louis Review, January/February, 93(1), pp. 37-48.

BIS Quarterly Review (several issues).

Commodity Price Index, Monthly Price, http://www.indexmundi.com/commodities/?commodity=commodity-priceindex\&months $=240$; Dow Jones Industrial Average, Historical Prices, $\mathrm{http}: / /$ finance.yahoo.com $/ \mathrm{q} / \mathrm{hp}$ ? $\mathrm{s}=\wedge \mathrm{dji}+$ historical+prices.

Domański, D., Heath, A. (2007), Financial investors and commodity markets, BIS Quarterly Review, March.

Dudziński, J. (2011), Motives, forms and directions of financial investors involvement in commodity markets, Trends in the World Economy, vol. 3.

Dudziński, J. (2010), Financial investors in international raw materials and food markets and price movements of those commodities, Economics \& Sociology Scientific Papers Vol. 3, No. 1, pp. 25-33.

Dudziński, J. (2009), Financial Factors in Price Movements of Primary Commodities on the International Market, Folia Oeconomica Stetinensia, vol. 8 (16), pp. 113-125.

Dwyer, A., Gardner, S., Williams, T. (2011), Global Commodity Markets - Price Volatility and Financialization, Bulletin Reserve Bank of Australia, June, pp.49-57.

EU wants to tame 'financialisation' of commodity markets, http:// www.euractiv.com/specialreport-rawmaterials/eu-wants-tame-financialisationcommodity-markets-news-502734.

Gilbert, Ch. L. (2010), Speculative Influences on Commodity Futures Prices, 2006-2008, UNCTAD Discussion Papers, No. 197, March.

Inamura, Y., Kimata, T., Kimura, T., Muto, T. (2011), Recent Surge In Global Commodity Prices, Bank Japan Review, pp.1-9.

Kosev, M., Williams, T. (2011), Exchange - traded Funds, RBA Bulletin, March, pp. 51-59.

Mayer, J. (2009), The growing interdependence between financial and commodity markets, UNCTAD Discussion Papers, No. 197, March. 
Ohana, S., Ohana, J. (2010), The Impossible Quest for Diversification, Commodity News, December .

Price Formation in Financialized Commodity Markets: The Role of Information (2011), UNCTAD, New York and Geneva.

Price Volatility in Food and Agricultural Markets: Policy Responses (2011), FAO, UNCTAD, June.

Sławiński, A. (2010), Wpływ globalnego kryzysu bankowego na bankowość centralnq, Ekonomista, No. 2, pp. 145-162.

Stoll, H.R., Whaley, R.E. (2009), Commodity index investing and commodity futures prices, Owen Graduate School of Management Vanderbilt University, Nashville, TN, September 10.

Tang, K., Xiong, W. (2010), Index investment and financialization of commodities, NBER, Working Paper No. 1638 Cambridge Mass, National Bureau of Economic Research, September.

The financialization of commodity markets (2009), Trade and Development Report, UNCTAD, New York.

Trade and Development Report (2009), UNCTAD, New York.

Trade and Development Report (2010), UNCTAD, New York.

Wray, L. R. ( 2008), The Commodities Market Bubble, The Levy Economics Institute of Bard College, Public Policy Brief, No. 96. 